\title{
9. CENOZOIC CALCAREOUS NANNOFOSSILS FROM THE LESSER ANTILLES FOREARC REGION AND BIOSTRATIGRAPHIC SUMMARY OF LEG 110 1
}

\author{
Murlene W. Clark ${ }^{2}$
}

\begin{abstract}
During Leg 110 of the Ocean Drilling Program, sediment was recovered from six sites in the vicinity of the Lesser Antilles Forearc. Hole 671B, drilled near the toe of the Barbados deformation front, was the first-ever penetration of the décollement between the underthrusting Atlantic Plate and the offscraped Barbados accretionary prism. Stratigraphic repetitions in sequence associated with tectonic movement along the décollement zone, first observed on DSDP Leg 78A, were further documented at four ODP Leg 110 sites. A significant biostratigraphic inversion is present at Site 671 at 128 mbsf in which upper Miocene sediments rest atop lower Pleistocene strata. Smaller repetitions in sequence are recorded at Sites $671,673,674$, and 676. Leg 110 sediments range from middle Eocene to early Pleistocene in age. Pliocene/Pleistocene assemblages are generally well preserved; however, Miocene assemblages have undergone extensive dissolution at all Leg 110 sites. Paleogene sediments are sometimes recrystallized and the nannofossils contained within exhibit a range in preservation from poor to good.
\end{abstract}

\section{INTRODUCTION}

Leg 110 originated in Bridgetown, Barbados, on June 26, 1986. The objectives of this Leg were to: (1) study active margin processes in the Lesser Antilles Forearc region and (2) achieve the first-ever penetration of a décollement zone between a descending crustal plate and the offscraped accretionary prism. Experience gained on DSDP Leg 78A, an earlier attempt to accomplish these goals, proved invaluable to the success of the Leg 110 mission. On July 4, 1986, the décollement separating the Barbados accretionary prism and the descending Atlantic Plate was penetrated. Reverse faulting, first recognized in Leg $78 \mathrm{~A}$ sediments, was further documented at Leg 110 sites. Lower Pleistocene to middle Eocene sediments were recovered on Leg 110. Upper Pleistocene sediments were consistently absent from recovered sections.

Five of the six sites drilled on Leg $110(671,673,674,675$, and 676) probed the deformed sediments of the Barbados accretionary prism (Fig.1) (Mascle, Moore, et al., 1988). Site 672 was drilled on the Atlantic abyssal plain as a stratigraphic reference section for sediments entering the accretionary complex. One reason the Barbados Forearc was chosen for active margin study is because equatorial Atlantic waters are characterized by a depressed calcite compensation depth (CCD), which results in improved biostratigraphic resolution. Nannofossil preservation is generally good for Pliocene/Pleistocene sediments; however, large-scale dissolution was observed in all but the uppermost Miocene assemblages. Dissolution within these sediments may have resulted from upward excursions of the CCD during the Miocene (Berger and von Rad, 1972; Van Andel, 1975). The Paleogene sequence is more deeply buried and subject to increased levels of diagenesis; its quality of preservation ranged from good to poor.

\section{METHODS}

Biostratigraphic descriptions of Leg 110 sediments were made from smear slides prepared according to standard techniques proposed by Bramlette and Sullivan (1961) and Hay (1961). One exception to the

\footnotetext{
${ }^{1}$ Moore, J. C., Mascle, A., et al., 1990. Proc. ODP, Sci. Results, 110: College Station, TX (Ocean Drilling Program).

2 Department of Geology-Geography, University of South Alabama, Mobile, Alabama 36688.
}

standard procedure was the use of the mounting medium Loctite so that the slides could be rapidly cured under ultraviolet light. Sediments from each Hole were routinely examined at an interval of one sample per core-section except in obviously barren sediment. Samples were observed through the light microscope at a magnification of $1000 \times$. Both crosspolarized and phase-contrast light were used for species identification.

The relative abundance of individual species was estimated by the methods proposed by Hay (1970). Estimates of species abundance are expressed in the following manner:

$\begin{array}{lll}\text { V } & \text { very abundant } & \text { over } 10 \text { specimens per field of view } \\ \text { A } & \text { abundant } & 1-10 \text { specimens per field of view } \\ \text { C } & \text { common } & 1 \text { specimen per } 2 \text { to } 10 \text { fields of view } \\ \text { F } & \text { few } & 1 \text { specimen per } 11 \text { to } 100 \text { fields of view } \\ \text { R } & \text { rare } & 1 \text { to } 2 \text { specimens per slide }\end{array}$

Lower case letters are used to represent the individual abundances of reworked species.

The overall abundance of nannofossil taxa in each sample was also estimated. The following scale was used to designate total abundance after Bergen (1984):

$\begin{array}{lll}\text { A } & \text { abundant } & \text { Nannofossils comprise over } 50 \% \text { of each slide } \\ \text { C } & \text { common } & \text { Betweem } 10 \text { amd } 50 \% \text { nannofossils } \\ \text { F } & \text { few } & \text { Between } 1 \text { and } 10 \% \text { annofossils } \\ \text { R } & \text { rare } & \text { Less than } 1 \% \text { nannofossils } \\ \text { B } & \text { barren } & \text { Slide totally barren of nannofossils }\end{array}$

The overall preservation of each sample is evaluated with respect to the following criteria:
G good
M moderate Specimens are etched and show signs of
Specimens show little evidence of dissolution or overgrowth overgrowth. Identification is generally not impaired except in the case of fragile forms which may be removed from the assemblage.
P poor
Specimens appear highly dissolved and/or
overgrown. Species diversity is greatly reduced.

\section{Nannofossil Zonation}

Biostratigraphic description of Leg 110 sediments is based on zonation schemes proposed by Okada and Bukry $(1980)$, Bukry $(1973,1975)$, and Gartner (1977). Eocene through Pliocene sediments are zoned according to the low-latitude scheme of Bukry $(1973,1975)$ as modified by Okada and Bukry (1980). Pleistocene sediments are zoned using the 


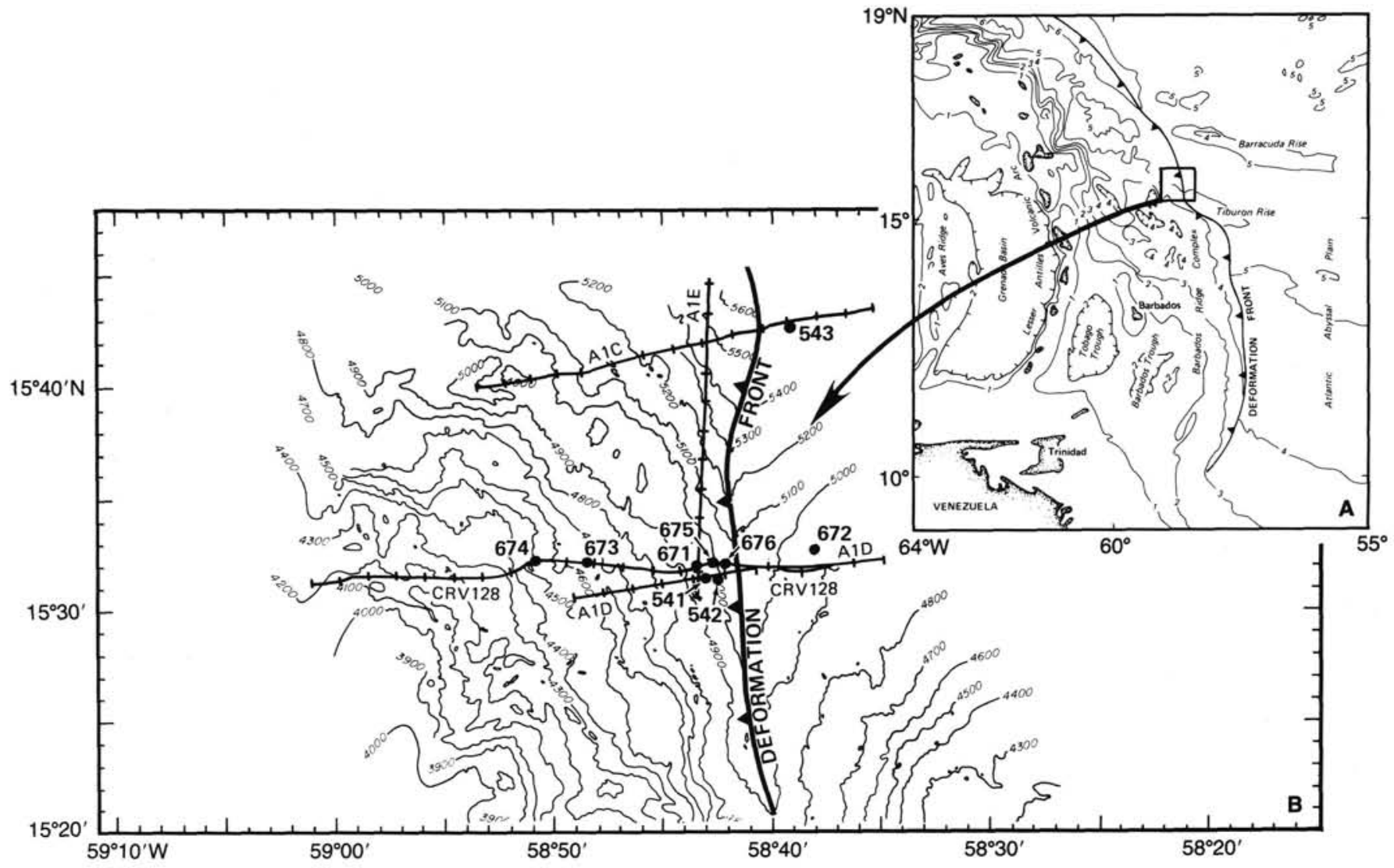

Figure 1. Location map of Leg 110 sites. Bathymetry in meters.

scheme of Gartner (1977) that affords better resolution in the Quaternary portion of the column. These two zonation schemes are easily combined because they both use the last occurrence of Discoaster brouweri to mark the Pliocene/Pleistocene boundary.

Emendations to the above zonation scheme are adopted in this report (Fig. 2) that conform more closely to the assemblage preserved at Leg 110 sites. Many of these changes were recommended by Bergen (1984) for samples recovered on Leg 78A.

The Pleistocene zonation of Gartner (1977) utilizes the acme of the small Gephyrocapsa species as a datum. Because gephyrocapsid assemblages are often adversely affected by dissolution at Leg 110 sites, this zone could not be consistently recognized and the Pseudoemiliania lacunosa Zone of Gartner (1977) is expanded to include this interval.

Refinements within the Amaurolithus tricorniculatus Zone of Okada and Bukry (1980) were possible, due to reasonably well-preserved lower Pliocene assemblages recovered from Sites 671 and 672 . As suggested by Bergen (1984), the base of Ceratolithus cristatus proved to be coincident with the highest occurrence of $C$. acutus. Because $C$. cristatus is common in the section, its base is a useful supplement to this $C$. acutus datum. C. ruqosus is not used as a marker in this study because it is rare and easily misidentified when the assemblage is overgrown.

According to the Okada and Bukry zonation (1980), the position of the Miocene/Pliocene boundary is indicated by the last occurrence of Triquetrorhabdulus ruqosus and/or the first occurrence of Ceratolithus acutus. Triquetrorhabdulus ruqosus is consistently found above the base of Ceratolithus acutus in the study area and is supplanted by C. acutus as the boundary marker in this report. The boundary between Zones $\mathrm{CN} 10$ and CN11 is indicated, according to the zonation of Okada and Bukry (1980), by the coincident last occurrence of Amaurolithus primus and $A$. tricorniculatus. A. tricorniculatus is the more reliable marker and is used alone in this study to divide the lower Pliocene section. Similarly, the last appearance datum (LAD) of Reticulofenestra pseudoumbilica is used to distinguish lower from upper Pliocene sediments.

The first occurrences of Discoaster surculus and $D$. berqqrenii are used by Okada and Bukry (1980) to indicate the base of the D. quinque- ramus Zone. The base of $D$. surculus was consistently found to occur above that of $D$. berqqrenii in Leg 110 and Leg 78A sediments (Bergen, 1984). Although the dissimilar first occurrences of these species may be an artifact of dissolution in the Barbados Forearc region, the first occurrence of $D$. berqqrenii has proven more reliable and is used here to designate the base on the $D$. quinqueramus Zone.

The revision of the early-late Oligocene boundary, as suggested by Berggren et al. (1985), will be adopted here. The Sphenolithus distentus Zone of Okada and Bukry (1980) is, consequently, reassigned to the early Oligocene.

\section{SITE SUMMARIES}

\section{Site 671}

Hole 671B, drilled near the toe of the Barbados Ridge complex, achieved penetration of the décollement between the descending Atlantic Plate and the offscraped Barbados accretionary prism. Sedimentological, structural, and geochemical evidence suggests that the décollement occurred between 501 and 510 mbsf (Core 110-671B-55X) within an extensive section of carbonate-poor claystones and mudstones. This interval could not be biostratigraphically zoned due to the absence of calcareous and siliceous microfossils.

Three hundred meters of calcareous mudstone and marlstone were recovered above the décollement interval. Two reverse faults were identified in this interval by means of nannofossil biostratigraphy. The largest of these emplaced an upper Miocene through lower Pleistocene section on top of a sequence spanning approximately the same age. A second fault was observed within this lower sequence, along which sediment from the early Pleistocene Calcidiscus macintyrei Zone was interjected into that of the late Pliocene Discoaster brouweri Zone. 


\begin{tabular}{|c|c|c|c|c|c|}
\hline AGE & \multicolumn{2}{|r|}{ ZONE } & & SUBZONE & DATUM \\
\hline \multirow{3}{*}{$\begin{array}{c}\text { lote } \\
\text { Pleistocene }\end{array}$} & \multicolumn{4}{|c|}{ Emilianio huxleyi ocme } & \\
\hline & \multicolumn{4}{|c|}{ Emiliania hux/uyi } & FAD E. hux/eyi ocmc \\
\hline & \multicolumn{4}{|c|}{ Gepiyrrcapsu oceanica } & FAD E. nux/eyi \\
\hline \multirow{3}{*}{$\begin{array}{c}\text { early } \\
\text { Pleistocene }\end{array}$} & \multicolumn{4}{|c|}{ Pserudocmilionia lacunosa } & LAD P. lacunosa \\
\hline & \multicolumn{4}{|c|}{ Helicosphacero sellii } & LAD H. scllii \\
\hline & \multicolumn{4}{|c|}{ Colcidiscus macintyrei } & LAD C. macintyrei \\
\hline \multirow{4}{*}{$\begin{array}{c}\text { lote } \\
\text { Pliocene }\end{array}$} & \multirow{4}{*}{ CN12 } & \multirow{4}{*}{$\begin{array}{l}\text { Discooster } \\
\text { brouweri }\end{array}$} & CNI2d & Calcidiscus macintyrei & LAD D. brouweri \\
\hline & & & $\mathrm{CN} / 2 \mathrm{C}$ & Discoaster pentaradiatus & LAD 0. pentaradiatus \\
\hline & & & $\mathrm{CN} I 2 \mathrm{~b}$ & Discooster surculus & LAD D. surculus \\
\hline & & & CNIZa & Discooster tomalis & LAD O. tamolis \\
\hline \multirow{4}{*}{$\begin{array}{l}\text { early } \\
\text { Pliocene }\end{array}$} & \multirow{2}{*}{$\mathrm{CN} I 1$} & \multirow{2}{*}{$\begin{array}{l}\text { Reticulotenestru } \\
\text { Pseudoumbilica }\end{array}$} & CN II & Discoaster asymmetricus & LAD R. pseudoumbilica \\
\hline & & & CNIIa & Sphenolithus neoabies & FAD $\quad 0$. osymmetriaus ocme \\
\hline & \multirow{3}{*}{ CN1O } & \multirow{3}{*}{$\begin{array}{l}\text { Amaurolithus } \\
\text { tricorniculutus }\end{array}$} & CN $10 \mathrm{C}$ & Ceratolithus rugosus & LAD A. tricorniculatus \\
\hline & & & CN IOb & Ceratolithus ocutus & $\begin{array}{l}A D \text { C. ocurus or } \\
\text { AL C. cristutus }\end{array}$ \\
\hline \multirow{6}{*}{$\begin{array}{l}\text { late } \\
\text { Miocene }\end{array}$} & & & CN 100 & Triquetrorhabdulus rugosus & DD C. acutus \\
\hline & \multirow{2}{*}{$\mathrm{CN} 9$} & \multirow{2}{*}{$\begin{array}{l}\text { Discooster } \\
\text { quinqueramus }\end{array}$} & CN 9b & Amaurolithus primus & AC C. quinqueramus \\
\hline & & & CN 9a & Discooster berggreniï & FAD A. primus \\
\hline & \multirow{2}{*}{ CN 8} & \multirow{2}{*}{$\begin{array}{l}\text { iscooster } \\
\text { neohamatus }\end{array}$} & CN $8 b$ & Discooster noorectus & FAD 0 . bergorenii \\
\hline & & & CN $8 a$ & Discoaster bellus & AD D ioeblichii \\
\hline & \multirow{2}{*}{$\mathrm{CN} 7$} & \multirow{2}{*}{$\begin{array}{l}\text { Discoaster } \\
\text { hamatus }\end{array}$} & $\mathrm{CN} 7 \mathrm{~b}$ & Cotinoster calyculus & AD D. hamatus \\
\hline \multirow{6}{*}{$\begin{array}{l}\text { middle } \\
\text { Miocene }\end{array}$} & & & $\mathrm{CN} 7 \mathrm{a}$ & Helicosphoera carteri & FAD C. colyculus \\
\hline & CN 6 & Cotinaster coalit & & & FAD D. homotus \\
\hline & & Discooster & CN $5 b$ & Discoaster kugleri & AD C. coalitus \\
\hline & $\cos 20$ & exilis & CN $5 a$ & Coccolithus miopelagicus & AD D. kugleri \\
\hline & CN 4 & Sphenolithus hete & rphus & & AD $S$. heteromorphus \\
\hline & CN 3 & Helicosphaera on & erto & & $\begin{array}{l}\text { LAD H. ampliaperto } \\
\text { FAD } S \text {. neteromorpnus or }\end{array}$ \\
\hline & CN 2 & Sphenolithus bele & & & D S. belem \\
\hline Miocene & & & $\mathrm{CN}$ ic & Discooster druggii & \\
\hline & CN 1 & $\begin{array}{l}\text { Triquetrorhobdulus } \\
\text { corinatus }\end{array}$ & CN Ib & Ciscooster deflondrei & AD 0. druggii \\
\hline & & & CN lo & Cyclicargolithus abisectus & $\begin{array}{l}\text { AD C. abisectus acme } \\
\text { AD S. cipereensis or }\end{array}$ \\
\hline $\begin{array}{l}\text { late } \\
\text { Oligocene }\end{array}$ & & Sphenolithus & CP $19 \mathrm{~b}$ & Dictyococcites bisectus & 10 0. bisectus \\
\hline & Cris a d a & ciperoensis & CP 190 & Cyclicargolithus floridonus & AD S. distentus \\
\hline & CP 18 & Sphenolithus dis & & & AD S. ciperoensis \\
\hline & CP 17 & Sphenolithus pre & ntus & & AD S. distentus \\
\hline $\begin{array}{l}\text { eorly } \\
\text { Oligocene }\end{array}$ & & & CP $16 \mathrm{c}$ & Reticulofenestro hilloe & $\begin{array}{l}\text { LAD } \\
\text { LAD } \\
R \text {. umbillae }\end{array}$ \\
\hline & CP 16 & Helicosphoera & CP $16 \mathrm{~b}$ & Coccolithus formosus & Ai C. formosus \\
\hline & & & CP 160 & Coccolithus subdistichus & I tic C. subdistichus acme \\
\hline late & & Discooster & CP $15 \mathrm{~b}$ & Isthmolithus recurvus & AC ... soipanensis \\
\hline Eocent: & CP 15 & barbadiensis & CP 150 & Chlosmolithus oamarvensis & FAD 1. recurvus \\
\hline middle & & Reticulofonestra & CP $14 \mathrm{~b}$ & Discooster soipanensis & LAC C. grondis \\
\hline Eocene & $\mathrm{CP} 14$ & umbilico & CP 140 & Otscoaster bifax & $A D$ C. solitus \\
\hline
\end{tabular}

Figure 2. Nannofossil zonation used in this study modified from Bukry (1973, 1975), Gartner (1977), Okada and Bukry (1980), and Bergen (1984). FAD = first appearance datum and LAD = last appearance datum. 
Recovery of a lower to upper Oligocene section below the décollement in Core 110-671B-58X (539.2 mbsf) is biostratigrapic evidence that the descending Atlantic Plate was penetrated. The Oligocene nannofossil sequence is interrupted by many barren intervals that have a large clastic component. These intervals almost certainly correspond with periods of clastic influx from the South American continent. Biostratigraphic zonation of Site 671 sediments is recorded in Table 1 (microfiche, back pocket).

The lower Pleistocene section was observed in Samples 110$671 \mathrm{~B}-1 \mathrm{H}-1,88-90 \mathrm{~cm}$, through 110-671B-5H-1, 75-77 cm. Within this interval, the Pseudoemiliania lacunosa Zone is recognized in Samples 110-671B-1H-1, 88-90 cm, through -3H-3, 78-80 cm.

The Helicosphaera sellii Zone is recognized in Samples 110$671 \mathrm{~B}-3 \mathrm{H}-4,78-80 \mathrm{~cm}$, through $-4 \mathrm{H}-2,80-82 \mathrm{~cm}$. Recognition of this zone is based on the presence of Helicosphaera sellii above the highest occurrence of Calcidiscus macintyrei. The first downhole occurrence of Calcidiscus macintyrei in Sample 110$671 \mathrm{~B}-4 \mathrm{H}-3,80-82 \mathrm{~cm}$, indicates the early Pleistocene Calcidiscus macintyrei Zone, which extends down through Sample 110671B-5H-1, 75-77 cm.

The Pliocene/Pleistocene boundary is delineated between Samples 110-671A-5H-1, 75-77 cm, and 110-671B-5H-2, 75-77 $\mathrm{cm}$, by the last occurrence datum of Discoaster brouweri. The late Pliocene $D$. brouweri Zone $(\mathrm{CN} 12)$ is present between Samples 110-671B-5H-2, 75-77 cm, and 110-671B-10H-1, 79-81 cm. Within this interval each of the four subzones proposed by Okada and Bukry (1980) are recognized. The Calcidiscus macintyrei Subzone (CN12d) extends from the highest occurrence of Discoaster brouweri down to the highest occurrence of $D$. pentaradiatus in Sample 110-671B-6H-2, 80-82 cm. D. triradiatus reaches its peak abundance near the middle of this interval. The $D$. pentaradiatus Subzone $(\mathrm{CN} 12 \mathrm{c})$ is recognized from the highest occurrence of $D$. pentaradiatus down to the highest occurrence of D. surculus in Sample 110-671B-6H-6, 80-82 cm. The D. surculus Subzone (CN12b) is present in Sample 110-671B-6H, 80-82 $\mathrm{cm}$, down through Sample 110-671B-7H-3, 79-81 cm.

The $D$. tamalis Subzone (CN12a) extends from the highest occurrence of D. tamalis in Sample 110-671B-7H-3, 79-81 cm, down to the last occurrence of Reticulofenestra pseudoumbilica in Sample 110-671B-10H-2, 79-81 cm. A four-rayed discoaster with bifurcate tips occurs within the upper Pliocene section, resembling $D$. tamalis, particularly under conditions of increased dissolution. This form is discussed in detail in the Appendix.

Samples 110-671B-10H-2, 79-81 cm, through 110-671B$11 \mathrm{X}-6,79-81 \mathrm{~cm}$, are assigned to the the early Pliocene Reticulofenestra pseudoumbilica Zone (CN11). Further subdivision of this zone was not possible because the beginning of the acme of D. asymmetricus could not be established.

All three subzones of the Amaurolithus tricorniculatus Zone (CN10) are recognized for Samples 110-671B-11X, CC, to $-12 \mathrm{X}, \mathrm{CC}$. The Ceratolithus ruqosus Subzone (CN10c), which coincides at this site with the range of Amaurolithus tricorniculatus, is determined for Samples 110-671B-11X, CC, and 110$671 \mathrm{~B}-12 \mathrm{X}-1,80-83 \mathrm{~cm}$. The early Pliocene $C$. acutus Subzone $(\mathrm{CN} 10 \mathrm{~b})$ is designated by the rare but consistent occurrence of C. acutus in Samples 110-671B-12X-2, 80-83 cm, through 110$671 \mathrm{~B}-12 \mathrm{X}-5,80-83 \mathrm{~cm}$. Sample 110-671B-12X, CC, is assigned to the late Miocene Triquetrorhabdulus ruqosus Subzone (CN10a) because both Ceratolithus acutus and Discoaster quinqueramus are absent.

Samples 110-671B-13X-1, 80-82 cm, through 110-671B$14 \mathrm{X}-6,74-76 \mathrm{~cm}$, are placed within the Amaurolithus primus Subzone (CN9b) of the Discoaster quinqueramus Zone. The assemblage, although poorly preserved, includes Discoaster quinqueramus, D. surculus, D. pentaradiatus, D. variabilis, Amaurolithus primus, and Reticulofenestra pseudoumbilica.
Below Sample 110-671B-14X-6, 74-76 cm, a thrust fault is evident and has placed upper Miocene sediment in Core 110671B-14X atop lower Pleistocene age sediment. Samples 110$671 \mathrm{~B}-14 \mathrm{X}, \mathrm{CC}$, through 110-671B-19X-1, 83-85 cm, are assigned to the early Pleistocene Pseudoemiliania lacunosa Zone of Gartner (1977). The lower Pleistocene section below the fault is thicker but less complete than the same interval above. In the lower section, the sediment of the $P$. lacunosa Zone appears to rest unconformably on top of that of the Calcidiscus macintyrei Zone. The intervening Helicosphaera sellii Zone was not identified. The Calcidiscus macintyrei Zone is determined for Samples 110-671B-19X, CC, through -23X-CC. A small interval of upper Pliocene sediment (containing Discoaster brouweri and $D$. triradiatus) is present within this interval (Samples 110-671B$22 \mathrm{X}-3,79-81 \mathrm{~cm}$, through $110-671 \mathrm{~B}-22 \mathrm{X}-6,79-81 \mathrm{~cm})$. This assemblage is indicative of the late Pliocene Calcidiscus macintyrei Subzone of Okada and Bukry (1980) and was very likely emplaced by additional reverse faulting.

The late Pliocene Calcidiscus macintyrei Subzone (CN12d) is again recognized in Samples 110-671B-24X-1, 80-82 cm, through 110-671B-25X-1, 80-82 cm. Between Samples 110-671B-24X-1, $80-82 \mathrm{~cm}$, and 110-671B-29X-3, 80-82 cm, all four late Pliocene subzones of Okada and Bukry (1980) are observed. These subzones are differentiated by the successive downhole highest occurrences of Discoaster pentaradiatus in Sample 110-671B25X-2, 80-82 cm, D. surculus in Sample 110-671B-26X-1, 79$81 \mathrm{~cm}$, and D. tamalis in Sample 110-671B-27X-1, 80-82 cm.

Samples 110-671B-29X, CC, through -33X, CC, are assigned to the Reticulofenestra pseudoumbilica Zone (CN11) of early Pliocene age. The Discoaster asymmetricus (CN11b) and Sphenolithus neoabies (CN11a) Subzones are readily discernible within this interval. The two subzones are separated by the base of the acme of D. asymmetricus, which occurs in Sample 110-671B$30 \mathrm{X}$, CC. Samples 110-671B-31X-1, 80-82 cm, through $-33 \mathrm{X}, \mathrm{CC}$, contain only rare specimens of $D$. asymmetricus.

Samples 110-671B-34X-1, 79-81 cm, through -37X-CC, are assigned to the Amaurolithus tricorniculatus Zone (CN10), which spans the Miocene/Pliocene boundary. All three of the Okada and Bukry (1980) subzones are recognized in this interval. The Ceratolithus ruqosus Subzone (CN10c) extends from the highest occurrence of Amaurolithus tricorniculatus down through Sample 110-671B-35X-6, 79-81 cm. The presence of Ceratolithus acutus in Sample 110-671-35X, CC, separates Subzone CN10c from the C. acutus Subzone (CN1Ob). The base of C. acutus in Sample 110-671B-37X-1, 79-81 cm, designates the bottom of the $C$. acutus Subzone, which has been correlated with the Miocene/Pliocene boundary. The Triquetrorhabdulus ruqosus Subzone (CN10a) of late Miocene age extends from the base of $C$. acutus down through Sample 110-671B-37X, CC.

Preservation declines sharply in Samples 110-671B-38X-1, $78-81 \mathrm{~cm}$, through $-42 \mathrm{X}, \mathrm{CC}$, which are assigned to the Amaurolithus primus Subzone (CN9b) of the Discoaster quinqueramus Zone. This interval contains an assemblage composed largely of discoasters. D. quinqueramus, D. surculus, $D$. brouweri, $D$. variabilis, and $D$. pentaradiatus are the principal assemblage components along with infrequent specimens of Amaurolithus primus. The abundance of placolith species may be selectively reduced by dissolution.

Samples 110-671B-43X-1, 79-81 cm, through -58X-5, 81-83 $\mathrm{cm}$, are largely barren of nannofossils with the exception of two poorly fossiliferous intervals. The first of these occurs between Samples 110-671B-46X-4, 77-80 cm, and $-46 \mathrm{X}, \mathrm{CC}$. This interval contains an assemblage which is indicative of the Discoaster berqqrenii Subzone (CN9a) of the late Miocene $D$. quinqueramus Zone. This assignment is based on the presence of $D$. berqqrenii without any Amaurolithus primus. Because $A$. primus is 
moderately susceptible to dissolution (Bergen, 1984), the absence of this species could be an artifact of sample preservation.

A second fossiliferous interval occurs between Samples 110671B-47X, CC, and $-48 \mathrm{X}-2,80-82 \mathrm{~cm}$, and contains rare specimens of $D$. hamatus, whose total range defines the $D$. hamatus Zone (CN7). No subzone designation could be made from the poorly preserved assemblage. $D$. bollii is present within this interval as well as in Sample 110-671B-48X-6, 80-82 cm. The $D$. neohamatus Zone $(\mathrm{CN} 8)$ is absent from the section.

The late Oligocene Dictyococcites bisectus Subzone (CP19b) of the Sphenolithus ciperoensis Zone is recognized in Samples 110-671B-58X, CC, through -60X, CC. This portion of the section is punctuated by barren intervals which alternate with wellpreserved nannofossiliferous sediment. Common Sphenolithus ciperoensis and Cyclicarqolithus abisectus occur within the assemblage as well as very abundant Cyclicarqolithus floridanus. Because the ranges of Sphenolithus ciperoensis and S. distentus were not observed to overlap at this site, the Cyclicarqolithus floridanus Subzone (CP19a) is assumed to be absent.

Sphenolithus distentus is encountered below the base of $S$. ciperoensis in Sample 110-671B-61X-4, 80-82 cm. The $S$. distentus Zone (CP18) of early Oligocene age is recognized in Samples $110-671 \mathrm{~B}-61 \mathrm{X}-4,80-82 \mathrm{~cm}$, through $-71 \mathrm{X}-4,26-28 \mathrm{~cm}$. This interval has been expanded by the influx of clastic sediment which corresponds with barren portions of the section. Sample 110-671B-71X, CC, contains no S. distentus or Reticulofenestra umbilica and is, therefore, assigned to the Sphenolithus predistentus Zone (CP17).

Samples 110-671B-72X-3, 120-122 cm, through $-72 \mathrm{X}, \mathrm{CC}$, contain few to rare specimens of Reticulofenestra umbilica and rare Coccolithus formosus. Although these species define the Coccolithus formosus Subzone (CP16b) of the Helicosphaera reticulata Zone, the low abundance of these forms is unusual and suggests that alternative zonations for the interval are possible. Cores 110-671B-73X and -74X are barren of nannofossils.

\section{Site 672}

Site 672 was drilled on the Atlantic abyssal plain, $6 \mathrm{~km}$ east of the Barbados deformation front (Fig 1). This site was selected as a biostratigraphic reference section for Leg 110 holes drilled into the more deformed sediments of the accretionary complex (Table 2, microfiche). One hundred sixty meters of Miocene to lower Pleistocene hemipelagic muds and claystones were recovered in the upper portion of this section. These deposits blanket nearly $340 \mathrm{~m}$ of lower Eocene through lower Miocene sediment. This lower portion is characterized by cyclical alternations between terrigenous influx from the South American continent and redeposited sediments from the vicinity of the Tiburon Rise. Because the sequence of clastic and redeposited material is overprinted by intervals of normal hemipelagic sedimentation, a rudimentary zonation of these sediments is possible.

Pliocene/Pleistocene assemblages are well preserved at Site 672 and show little effect from dissolution even at an estimated water depth of greater than $4000 \mathrm{~m}$. This is consistent with estimates for the modern CCD in this region placed at $5200 \mathrm{~m}$ by Wright (1984). Conversely, Miocene assemblages appear highly dissolved and may have experienced increased levels of dissolution due to an elevation of the CCD (Berger and von Rad, 1972; Van Andel, 1975). Intervals barren of carbonate within the Miocene section have been identified as lower Miocene by radiolarian assemblages (Mascle, Moore, et al., 1988). Oligocene assemblages are moderately well preserved, although the Oligocene sequence is punctuated by unfossiliferous redeposited sediment layers. Middle to upper Eocene carbonate sediments are highly indurated and yield nannofossil assemblages of poor to moderate quality. Overgrowth and recrystallization of specimens is common in the Eocene section.
Samples 110-672A-lH-1, 71-73 cm, through $-4 \mathrm{H}, \mathrm{CC}$, belong to the early Pleistocene Pseudoemiliania lacunosa Zone. The nominative species occurs within this interval above the highest occurrence of Helicosphaera sellii. Calcidiscus macintyrei and Helicosphaera sellii are first observed downhole in Sample $110-672 \mathrm{~A}-5 \mathrm{H}-1,80-82 \mathrm{~cm}$. The coincident highest occurrences of these two species indicates that the $H$. sellii Zone is missing. The Calcidiscus macintyrei Zone extends from Sample $110-672 \mathrm{~A}-5 \mathrm{H}-1,80-82 \mathrm{~cm}$, through $-5 \mathrm{H}-3,80-82 \mathrm{~cm}$, based on the presence of $C$. macintyrei above the highest occurrence of Discoaster brouweri.

The Pliocene/Pleistocene boundary is indicated by the first downhole occurrence of $D$. brouweri in Sample 110-672A-5H-4, $80-82 \mathrm{~cm}$. The four late Pliocene subzones of Okada and Bukry (1980) are again recognized. This suggests that a complete upper Pliocene section was recovered at Site 672. The highest consistent occurrence of $D$. pentaradiatus in Sample 110-672A-6H-4, 98-100 cm, marks the top of the $D$. pentaradiatus Subzone (CN12c), which extends down through Sample 110-672A-6H-6, $98-100 \mathrm{~cm}$. Rare reworked specimens of $D$. pentaradiatus were noted in the Calcidiscus macintyrei Subzone (CN12d) above (Samples 110-672A-5H-4, 80-82 cm, to $110-672 \mathrm{~A}-6 \mathrm{H}-4,98-100$ $\mathrm{cm})$. The $D$. surculus Subzone $(\mathrm{CN} 12 \mathrm{~b})$ is recognized in Samples $110-672 \mathrm{~A}-6 \mathrm{H}, \mathrm{CC}$, through $-7 \mathrm{H}-3,80-82 \mathrm{~cm}$, above the highest occurrence of $D$. tamalis.

D. tamalis is first observed downhole in Sample 110-672A$7 \mathrm{H}-4,80-82 \mathrm{~cm}$, where it defines the top of the $D$. tamalis Subzone $(\mathrm{CN} 12 \mathrm{a})$. This is a relatively thick interval $(27 \mathrm{~m})$ that extends down through Sample 110-672A-10H-3, 80-82 cm. Four rayed forms similar in appearance to $D$. tamalis (as seen at Site 671 ) occur in the Discoaster surculus Subzone above. The upper boundary of the $D$. tamalis Subzone is conservatively placed and could perhaps have been extended upward had samples been well preserved.

The lower Pliocene section at Site $\mathbf{6 7 2}$ is also complete. The top of the lower Pliocene is marked by the highest occurrence of Reticulofenestra pseudoumbilica in Sample 110-672A-10H-4, $80-82 \mathrm{~cm}$. The $R$. pseudoumbilica Zone (CN11), which extends down through Sample 110-672A-12H-1, 82-84 cm, is divided into subzones on the acme of Discoaster asymmetricus. A sharp decline in the abundance of $D$. asymmetricus below Sample $110-672 \mathrm{~A}-11 \mathrm{H}-1,76-78 \mathrm{~cm}$, serves to separate the $D$. asymmetricus Subzone (CN11b) from the Sphenolithus abies Subzone (CN11a).

Samples 110-672A-12H-2, 82-84 cm, through -13H-3, 97-99 $\mathrm{cm}$, are assigned to the Amaurolithus tricorniculatus Zone (CN10). The top of this zone is designated by the highest occurrence of $A$. tricorniculatus. Within this interval three subzones are recognized. The Ceratolithus ruqosus Subzone (CN10c) is defined by the presence of Amaurolithus tricorniculatus above the highest occurrence of Ceratolithus acutus in Samples 110$672 \mathrm{~A}-12 \mathrm{H}-2,82-84 \mathrm{~cm}$, through $110-672 \mathrm{~A}-12 \mathrm{H}-5,82-84 \mathrm{~cm}$. The C. acutus Subzone $(\mathrm{CN} 10 \mathrm{~b})$ is defined by the range of $C$. acutus. This species is rare but very well preserved in Samples 110$672 \mathrm{~A}-12 \mathrm{H}-6,82-84 \mathrm{~cm}$, through $13 \mathrm{H}-2,87-89 \mathrm{~cm}$. The base of Ceratolithus acutus defines the position of the Miocene/Pliocene boundary.

The Triquetrorhabdulus ruqosus Subzone (CN10a) of latest Miocene age is an interval zone between the first occurrence of Ceratolithus acutus and the last occurrence of Discoaster quinqueramus. These criteria are met in Sample 110-672A-13H-3, 97-99 cm, which alone represents Subzone CN10a of Okada and Bukry (1980).

Discoaster quinqueramus and Amaurolithus primus are present in Samples 110-672A-13H-4, 97-99 cm, through -15X-2, 70$72 \mathrm{~cm}$. These species identify the $A$. primus Subzone (CN9b) of the Discoaster quinqueramus Zone. Preservation within this in- 
terval is poor to moderate and deteriorates rapidly downhole. Samples 110-672A-15X-3, 70-72 cm, through 17X-2, 110-112 $\mathrm{cm}$, are totally barren of nannofossils. The Discoaster berqqrenii Subzone (CN9a) is identified in Samples 110-672A-17X-3, $110-112 \mathrm{~cm}$, through $-18 \times-4,39-41 \mathrm{~cm}$, from a poorly preserved assemblage that contains $D$. berggrenii without Amaurolithus primus or Discoaster quinqueramus. Most placoliths were absent from the assemblage due to the effects of dissolution.

Samples 110-672A-18X-4, 50-52 cm, and -18X-CC, contain a poorly preserved Miocene assemblage that includes rare specimens of $D$. hamatus. This interval is assigned to the $D$. hamatus Zone ( $\mathrm{CN} 7)$; no subzone designation could be determined from the sparse assemblage. The fact that the Discoaster neohamatus Zone (CN8) was not observed at Site 672 may suggest the presence of a hiatus. Below Sample 110-672A-18X, CC, a long interval exists that is barren of calcareous microfossils.

Samples 110-672A-26X-1, 86-88 cm, through -28X, CC, contain a well-preserved late Oligocene assemblage in which common Sphenolithus ciperoensis are observed without $S$. distentus. This suggests an age assignment for this interval within the $S$. ciperoensis Zone (CP19b). No sample at this site contains both $S$. ciperoensis and $S$. distentus; therefore, Subzone CP19a is probably missing from the section.

$S$. distentus first appears downhole in Sample 110-672A$29 \mathrm{X}-1,85-87 \mathrm{~cm}$, and is present through a lengthy carbonate section $(76 \mathrm{~m})$ interspersed with clastic deposits. As at Site 671 the expanded nature of the $S$. distentus section may be explained by the influx of sediment from the South American coast and from the nearby Tiburon Rise. The base of the early Oligocene $S$. distentus Zone (CP18) is placed directly below Sample 110$672 \mathrm{~A}-37 \mathrm{X}-1,67-69 \mathrm{~cm}$. This sample also contains specimens of Reticulofenestra umbilica and Coccolithus formosus that have been reworked from older deposits.

An interval predominantly barren of nannofossils occurs in Samples 110-672A-37X-2, 67-69 cm, through -38X, CC. These samples separate the $S$. distentus Zone (CP18) and the Eocene deposits at the base of the section. Sample 110-672A-37X-6, 67$69 \mathrm{~cm}$ contains a poor assemblage of early Oligocene nannofossils that includes Reticulofenestra umbilica without Sphenolithus distentus. Due to its poor state of preservation, this sample is tentatively placed within the Helicosphaera reticulata Zone (CP16). The Sphenolithus predistentus Zone (CN17) was not observed in the section.

Poor to moderately preserved Eocene assemblages are observed in Samples 110-672A-39X-2, 26-28 cm, through -49 X-2, $70-72 \mathrm{~cm}$. This section is well indurated and somewhat recrystallized. The Discoaster barbadiensis Zone (CP15) occurs in Samples 110-672A-39X-2, 26-28 cm, through -40X-5, 13-15 cm, due to the presence of $D$. barbadiensis and $D$. saipanensis within the interval.

The co-occurrence of Chiasmolithus qrandis and Reticulofenestra umbilica defines the middle Eocene Reticulofenestra umbilica Zone (CN14) in Samples 110-672A-40X-6, 44-46 cm, through $-49 \mathrm{X}-2,70-72 \mathrm{~cm}$. Chiasmolithus qrandis is rare and occurs sporadically throughout the upper portion of this zone due to poor sample preservation and reduced nannofossil abundances. The fairly consistent occurrence of $C$. solitus in Samples $110-672 \mathrm{~A}-44 \mathrm{X}-3,59-61 \mathrm{~cm}$, through $-49 \mathrm{X}-2,70-72 \mathrm{~cm}$, suggests that Subzone CP14a of the Reticulofenestra umbilica Zone is present. Subzone CP14b is recognized at this site between the highest occurrence of Chiasmolithus qrandis and the highest consistent occurrence of $C$. solitus. The subzone boundary between Subzones CP14a and CP14b is dashed in Table 2 due to the poor sample preservation throughout the middle Eocene interval.

\section{Site 673}

Site 673 was drilled in a highly deformed portion of the accretionary prism located $12 \mathrm{~km}$ west of the deformation front. The $330 \mathrm{~m}$ of sediment recovered at Hole $673 \mathrm{~B}$ consists of a Miocene sequence of siliceous rich clays overlain by a thin package of Pliocene/Pleistocene carbonates (Table 3, microfiche, back pocket). Nannofossiliferous sediments are confined almost exclusively to Cores $110-673 \mathrm{~B}-1 \mathrm{H}$ through $-4 \mathrm{H}$.

No upper Pleistocene sediments are observed at this site. Samples 110-673B-lH-1, 80-82 cm, through -3H-4, 80-82 cm, contain Pseudoemiliania lacunosa without Helicosphaera sellii and are assigned to the early Pleistocene Pseudoemiliania lacunosa Zone. This sequence is interrupted by two barren intervals within Core 110-673B-2H.

The Helicosphaera sellii Zone, also of early Pleistocene age, was recognized in Samples 110-673B-3H-5, 80-82 cm, through $-4 \mathrm{H}-2,80-82 \mathrm{~cm}$ by the presence of $H$. sellii above the highest occurrence of Calcidiscus macintyrei. This zone is absent in the lower repeated sequence at Site 671 perhaps due to the effects of dissolution. The basal Pleistocene section represented by the Calcidiscus macintyrei Zone is present in Samples 110-673B$4 \mathrm{H}-3,80-82 \mathrm{~cm}$, through $-4 \mathrm{H}-5,80-82 \mathrm{~cm}$.

The Pliocene/Pleistocene boundary is marked just above Sample 110-673B-4H-6, 80-82 cm, which contains Discoaster brouweri. Although the lower Pleistocene section appears continuous, only an incomplete record of the upper Pliocene section was recovered at this site. Samples 110-673B-4H-6, 80-82 $\mathrm{cm}$, through $-5 \mathrm{H}-1,79-82 \mathrm{~cm}$, are latest Pliocene in age and are placed within the Calcidiscus macintyrei Subzone (CN12d) of the Discoaster brouweri Zone. Sample 110-673B-5H-2, 79-81 $\mathrm{cm}$, contains $D$. tamalis, $D$. surculus, and $D$. pentaradiatus as important assemblage components and is therefore assigned to the $D$. tamalis Subzone (CN12a). The simultaneous downhole appearance of these species is strongly indicative of missing sections. The $D$. fentaradiatus $(\mathrm{CN} 12 \mathrm{c})$ and $D$. surculus $(\mathrm{CN} 12 \mathrm{~b})$ Subzones were not observed in the Site 673 sequence. This interval may have been removed by dissolution or as a result of faulting within the accretionary prism.

Below Sample 110-672A-5H-2, 79-81 cm, sediments are nearly barren of calcareous microfossils. Samples 110-673B$8 \mathrm{X}-2,142-144 \mathrm{~cm}$, through $-8 \mathrm{X}-3,29-31 \mathrm{~cm}$, and $-17 \mathrm{X}-4,127-$ $130 \mathrm{~cm}$, through $-18 \mathrm{X}-3,30-32 \mathrm{~cm}$, do, however, contain a moderately well-preserved assemblage of early Miocene nannofossils. The coincident occurrence of Sphenolithus heteromorphus and Helicosphaera ampliaperta places these samples within the $H$. ampliaperta Zone (CN3).

Radiolarian assemblages indicate an early Miocene age for the interval from Core 110-672A-8X down through -35X. Multiple reversals in radiolarian biostratigraphy define numerous thrust faults in this portion of the section.

\section{Site 674}

Hole 674 is located on the lower slope of the Barbados accretionary complex. At this location intensely deformed sediments were recovered that facilitated the study of accretionary deposits arcward of the deformation front. The biostratigraphy at this site is understandably complex (Table 4, microfiche) and is influenced by at least two reverse faults. Barren intervals and missing zones frequently interrupt the biostratigraphic sequence.

Samples $110-674 \mathrm{~A}-1 \mathrm{H}-1,68-70 \mathrm{~cm}$, through $-2 \mathrm{H}-2,86-88$ $\mathrm{cm}$, occur within the early Pleistocene Pseudoemiliania lacunosa Zone due to the presence of $P$. lacunosa above the highest occurrence of Helicosphaera sellii. A long barren interval, presumably of early Pleistocene age, is observed between Samples 
110-674A-2H-4, 86-88 cm, and $-5 \mathrm{X}-3,99-101 \mathrm{~cm}$. Two samples within this interval contain a poor assemblage of nannofossils that could not be reliably zoned. Lower Pleistocene sediments are recognized below the barren interval in Samples 110-674A$5 \mathrm{X}-4,99-101 \mathrm{~cm}$, through $-6 \mathrm{X}-2,80-82 \mathrm{~cm}$. These sediments are assigned to the Calcidiscus macintyrei Zone based on the presence of $C$. macintyrei and Helicosphaera sellii above the highest consistent occurrence of Discoaster brouweri. Discoaster species are present in this interval and are almost certainly the result of reworking. The Helicosphaera sellii Zone was not detected within the early Pleistocene section at Site 674; this zone was also missing at Site 672 .

The highest consistent occurrence of Discoaster brouweri designates the top of the Pliocene in Sample 110-674A-6X-3, 80-82 $\mathrm{cm}$. The four subzones of the $D$. brouweri Zone are recognized in the section between Sample 110-674A-6X-3, 80-82 cm, and $-7 \mathrm{X}, \mathrm{CC}$. This zone is quite thin when compared with the same interval at the other Leg 110 sites. The Calcidiscus macintyrei Subzone $(\mathrm{CN} 12 \mathrm{~d})$ is recognized down through Sample $-6 \mathrm{X}, \mathrm{CC}$. Sample 110-674A-7X-1, 78-80 cm, contains Discoaster pentaradiatus above the highest occurrence of $D$. surculus and is assigned to the $D$. pentaradiatus Subzone (CN12c). Sample 110$674 \mathrm{~A}-7 \mathrm{X}-2,78-80 \mathrm{~cm}$, is assigned to the $D$. surculus Zone (CN12b) due to the presence of the nominative species above the last occurrence of $D$. tamalis. The $D$. tamalis Subzone (CN12a) extends from Sample 110-674A-7X-3, 78-80 cm, down through $-7 \mathrm{X}, \mathrm{CC}$.

In Sample 110-674A-8X-1, 85-87 cm, the Discoaster pentaradiatus Subzone $(\mathrm{CN} 12 \mathrm{c})$ is repeated. Below this the $D$. tamalis Subzone (CN12a) also recurs in the section in Samples 110$674 \mathrm{~A}-12 \mathrm{X}-1,70-72 \mathrm{~cm}$ through $-13 \mathrm{X}-4,80-82 \mathrm{~cm}$. These subzones are separated by a barren interval of unknown age. Repetition of these late Pliocene subzones indicates the presence of a reverse thrust fault below Sample 110-674A-7X, CC.

The early Pliocene is represented only by Sample 110-674A$14 \mathrm{X}-1,13-15 \mathrm{~cm}$, which is placed within the Discoaster asymmetricus Subzone (CN11b) of the Reticulofenestra pseudoumbilica Zone. Assignment to the $D$. asymmetricus Subzone is based on the common occurrence of $D$. asymmetricus within the interval. Below this sample a long barren interval persists down to Sample 110-674A-28X-3, 4-7 cm, at which point Eocene sediments are encountered. The intervening barren interval is Miocene in age based on radiolarian biostratigraphy.

Samples 110-674A-28X-3, 4-7 cm, through 31X-2, 107-109 $\mathrm{cm}$, are placed within the Discoaster bifax Subzone (CP14a) of the Reticulofenestra umbilica Zone, which is middle Eocene in age. Chiasmolithus qrandis, C. solitus, and Reticulofenestra umbilica indicate the above age designation. Preservation is poor to moderate in these samples, and overgrowth of Chiasmolithus and Discoaster species is common.

Samples 110-674A-31X, CC, through -48X, CC, are barren of nannofossils with the exception of a poorly preserved assemblage observed in Samples 110-674A-33X-2, 50-52 cm, through $-674 \mathrm{~A}-33 \mathrm{X}-3,68-70 \mathrm{~cm}$. Although the age of these samples appears to be Miocene, exact zonation was not possible. Late Miocene species such as Discoaster quinqueramus occur together with early to middle Miocene species such as Sphenolithus heteromorphus in Sample 110-674A-33X-2, 50-52 cm. The presence of a Miocene assemblage below Eocene sediments is indicative of additional thrust faulting at this point in the section.

\section{Site 675}

Site 675 was drilled on the lower slope of the Barbados Forearc (Fig. 1). After a mudline core was taken, the hole was washed to a depth of $363 \mathrm{mbsf}$ where $67 \mathrm{~m}$ of sediment were cored. The mudline core was found to be early Pleistocene in age due to the presence of an assemblage that contained Calcidiscus macintyrei, Helicosphaera sellii, and Pseudoemiliania lacunosa in the core-catcher sample. Cores $110-675 \mathrm{~A}-2 \mathrm{X}$ through $-8 \mathrm{X}$ recovered from the bottom of the hole were barren of calcareous microfossils.

\section{Site 676}

Hole 676A was drilled at the toe of the Barbados accretionary wedge, $250 \mathrm{~m}$ arcward of the deformation front (Fig. 1). Three hundred ten meters of sediment were cored that ranged from early Pleistocene to middle Miocene in age (Table 5, microfiche). Preservation is moderate to good throughout the Pliocene/Pleistocene section but deteriorates markedly downhole as Miocene sediments become progressively depleted in carbonate.

Reverse faults are recognized within the lower Pleistocene and upper Miocene sections by the repetition of portions of the biostratigraphic sequence. The section appears to be otherwise complete with the exception of a small biostratigraphic gap that occurs near the Miocene/Pliocene boundary.

Samples 110-676A-lH-1, 66-68 cm, through -3H-5, 84-86 cm, are placed within the Pseudoemiliania lacunosa Zone of early Pleistocene age. No upper Pleistocene sediments were encountered at this site.

Due to the presence of Helicosphaera sellii, the interval between Samples 110-676A-3H-6, 84-86 cm, and -4H-6, 80-82 cm, is assigned to the early Pleistocene $H$. sellii Zone. In Sample $110-676 \mathrm{~A}-4 \mathrm{H}, \mathrm{CC}$, through $-6 \mathrm{H}-2,81-83 \mathrm{~cm}, \mathrm{H}$. sellii is absent from the assemblage, and repetition of the Pseudoemiliania lacunosa Zone is indicated. The recurrence of the Helicosphaera sellii Zone in Samples 110-676A-6H-3, 81-83 cm, through $-6 \mathrm{H}, \mathrm{CC}$, further supports the presence of at least one reverse fault at this point in the section. Large specimens of Calcidiscus leptoporus occur within the Helicosphaera sellii Zone that are very similar to $C$. macintyrei. $C$. macintyrei is distinguished on the basis of an open central area and a well-developed collar.

Samples 110-676A-7H-1, 80-82 cm, through 7H-6, 80-82 cm, are assigned to the early Pleistocene Calcidiscus macintyrei Zone. C. macintyrei is common to abundant in this well-preserved section. Helicosphaera sellii is present but less abundant than $\mathrm{Cal}$ cidiscus macintyrei.

The Pliocene/Pleistocene boundary occurs between Samples 110-676A-7H-6, 80-82 cm, and 7H-7, 60-62 cm. Infrequent specimens of Discoaster brouweri and an increase in the abundance of $D$. triradiatus downhole signal the top of the Pliocene section in Sample 110-676A-7H-7, 60-62 cm. Because Samples 110-676A-7H-7, 60-62 cm, through $-9 \mathrm{H}-1,80-82 \mathrm{~cm}$, do not consistently contain $D$. pentaradiatus, they are placed within the Calcidiscus macintyrei Subzone (CN12d) of the Discoaster brouweri Zone. D. brouweri is consistently reworked into the Pleistocene sediments of Site 676 as are specimens of $D$. pentaradiatus, $D$. surculus, and $D$. variabilis. Sphenolithus abies and Cyclicarqolithus floridanus are commonly reworked throughout the section.

Two samples, 110-676A-9H-2, 80-82 cm, and 110-676A-9H-3, $80-82 \mathrm{~cm}$, contain Discoaster pentaradiatus without $D$. surculus and are assigned to the $D$. pentaradiatus Subzone (CN12c) of the $D$. brouweri Zone. D. surculus occurs in Sample 110-676A$9 \mathrm{H}-4,80-82 \mathrm{~cm}$, and designates the top of the $D$. surculus Subzone (CN12b) that extends through Sample 110-676A-10-5, $16-18 \mathrm{~cm}$.

The Discoaster tamalis Subzone (CN12a) is recognized in Samples $110-676 \mathrm{~A}-10 \mathrm{H}-6,16-18 \mathrm{~cm}$, through $-13 \mathrm{X}-5,80-82 \mathrm{~cm}$. The top of this interval is defined by the highest consistent occurrence of $D$. tamalis due to the fact that rare specimens of $D$. tamalis are reworked into the D. surculus Subzone. 
The boundary between the upper and lower Pliocene is indicated by the highest occurrence of Reticulofenestra pseudoumbilica in Sample 110-676A-13X-6, 80-82 cm. The $R$. pseudoumbilica Zone (CN11) of early Pliocene age extends from Sample $110-676 \mathrm{~A}-13-6,80-82 \mathrm{~cm}$, through $-15 \mathrm{X}, \mathrm{CC}$. The boundary between Subzones CN11a and CN11b is designated by the beginning of the acme of Discoaster asymmetricus between Samples $110-676 \mathrm{~A}-13 \mathrm{X}, \mathrm{CC}$, and $-14 \mathrm{X}-1,8-10 \mathrm{~cm}$.

Samples 110-676A-16X-1, 80-82 cm, through -16X, CC, contain Amaurolithus tricorniculatus and Ceratolithus cristatus without $C$. acutus and are assigned to Subzone CN10c of the Amaurolithus tricorniculatus Zone. Subzone CN10b, which is defined by the total range of Ceratolithus acutus, was not observed at this site. The absence of $C$. acutus is indicative of missing section at the Miocene/Pliocene boundary. Subzone CN10a is recognized in Sample 110-676A-17X-1, 100-102 cm, by the absence of C. acutus, C. cristatus, Amaurolithus tricorniculatus, and Discoaster quinqueramus. Preservation within Zone CN10 is noticeably poorer than in the Pliocene/Pleistocene section above.

Discoaster quinqueramus is well represented in Samples 110$676 \mathrm{~A}-17 \mathrm{X}-2,100-102 \mathrm{~cm}$, through $-18 \mathrm{X}-6,30-32 \mathrm{~cm}$, although preservation of the overall assemblage is poor. This interval is assigned to the Amaurolithus primus Subzone (CN9b) of the Discoaster quinqueramus Zone due to the co-occurrence of $D$. quinqueramus and Amaurolithus primus.

The Discoaster quinqueramus Zone contains an interval between Samples 110-676A-18X-7, 30-32 cm, and -20X, CC, that is barren of calcareous microfossils. The Discosater berqqrenii Subzone (CN9a) of the D. quinqueramus Zone is recognized in Samples 110-676A-21X-1, 50-52 cm, through -21X-3, 50-52 cm, below the barren interval. The CN9a assemblage has undergone selective removal of all but the most dissolution-resistant species. Discoaster berqqrenii, D. brouweri, D. pentaradiatus, and D. variabilis are the dominant assemblage components that remain. It is possible that the amauroliths have also been removed from the assemblage by dissolution; however, the presence of this group in dissolved sediments slightly higher in the section indicates otherwise. Very large specimens of $D$. braarudii $(20 \mu \mathrm{m})$ are outstanding in the interval. In this report $D$. braarudii and $D$. brouweri are combined on range charts because overgrowth and dissolution in many portions of the Leg 110 section does not allow the consistent differentiation of these species.

Samples 110-676A-21-4X, 50-42 cm, through -22X-1, 80-82 $\mathrm{cm}$, contain few nannofossils and were not assigned to a specific zone. Samples 110-676A-22X-2, 80-82 cm, through -22X-5, 80$82 \mathrm{~cm}$, contain a poorly preserved and depauperate assemblage assigned to the Discoaster neohamatus Zone (CN8). This zonal designation is based on the common occurrence of $D$. neohamatus in the absence of $D$. berqqrenii and $D$. hamatus. The $D$. hamatus Zone (CN7) is identified in Sample 110-676A-22X, $C C$, by the presence of $D$. neohamatus, $D$. bollii, and six-rayed specimens of $D$. hamatus. Due to poor sample preservation a more refined zonation of this sample could not be obtained.

The $D$. berqqrenii Subzone $(\mathrm{CN} 9 \mathrm{a})$ is again encountered in the section between Samples 110-676A-23X-7, 80-82 cm, and $24 \mathrm{X}-5,80-82 \mathrm{~cm}$. This assemblage occurs below a barren interval between Samples 110-676A-23X-1, 80-82 cm, and 23X-6, $80-82 \mathrm{~cm}$, and is indicative of reverse faulting. Samples 110$676 \mathrm{~A}-24 \mathrm{X}, \mathrm{CC}$, through $-25 \mathrm{X}-2,70-72 \mathrm{~cm}$, are part of the repeated sequence as well, and are assigned to the $D$. neohamatus Zone (CN8) based on the absence of $D$. berqqrenii and $D$. hamatus. This interval is very poorly preserved and most of the easily dissolved assemblage components have been selectively removed.

Below Sample 110-676A-25X-2, 70-72 cm, the section is barren or contains so few specimens that zonation is indeterminate.

\section{CORRELATIONS}

Hole $672 \mathrm{~A}$ was drilled as a reference section for the deformed sediments of the Barbados accretionary prism. A nearly complete section was recovered at this site between the early Pleistocene Pseudoemiliania lacunosa Zone down through the late Miocene Discoaster bergqrenii Subzone (CN9a) of the D. quinqueramus Zone. Only the early Pleistocene Helicosphaera sellii Zone was not recognized in the section. This sequence is representative of Neogene sediments at Sites 671, 676, and at Site 541 (recovered on Leg 78A to the Lesser Antilles Forearc region). Although the $H$. sellii Zone was absent from Site 672 , as it was in the Pleistocene section at Site 671 below the fault and at Site 674 , it is present at Sites 673, 676, 541, and in the Pleistocene section above the fault at Site 671 (Fig. 3). Sites 673 and 674 have undergone intense deformation and contain Pliocene/Pleistocene sediments that exhibit numerous gaps in the biostratigraphic sequence so that comparisons with the reference site are difficult.

Preservation is significantly reduced for Neogene sediments at all Leg 110 sites below the Discoaster quinqueramus Zone (CN9). Only the D. hamatus Zone (CN7) is recognized at Site 672 between The $D$. quinqueramus Zone (CN9) and the top of the Oligocene section. The $D$. neohamatus $(\mathrm{CN} 8)$ and $D$. hamatus (CN7) Zones were recognized at Site 676 and the Helicosphaera ampliaperta Zone (CN3) was recognized at Site 673 from a middle to lower Miocene sequence otherwise barren of calcareous microfossils. Radiolarians provide more detailed biostratigraphic information at Sites $672,673,675$, and 676 for this interval (Fig. 3) and establish an early Miocene age for sediments in this highly dissolved portion of the column (Mascle, Moore, et al., 1988).

Oligocene sediments were identified only at Sites 671, 672, and 674. At Site 672 the Sphenolithus ciperoensis Zone (CP19), the $S$. distentus Zone (CP18), and the Helicosphaera reticulata Zone (CP16), are present. The Sphenolithus predistentus Zone (CP17) is not recognized in the Site 672 section but is observed in the more complete Oligocene sequence recovered at Site 671. At both sites the $S$. distentus section is expanded by clastic influx from the South American continent. The Cyclicarqolithus floridanus Subzone (CP19a) was not observed at either Site 671 or 672 and may be missing from the section. Oligocene nannofossil zonations are coroborated by planktonic foraminifer ages at Site 672 (Mascle, Moore, et al., 1988). Radiolarian biostratigraphy at Site 674 indicates that early Oligocene-aged sediments were interjected into the sequence in Cores 110-674A$10 \mathrm{X},-11 \mathrm{X},-28 \mathrm{X},-31 \mathrm{X}$ to $-33 \mathrm{X}$, and $-38 \mathrm{X}$ to $-41 \mathrm{X}$, probably by reverse faulting (Mascle, Moore, et al., 1988).

A middle to upper Eocene sequence occurs at Site 672 that extends from the Discoaster barbadiensis Zone (CP15) down through the Discoaster bifax Subzone (CP14a) of the Reticulofenestra umbilica Zone. A middle Eocene age for this portion of the sequence is supported by planktonic foraminifer biostratigraphy. Middle to early Eocene radiolarian zones are recognized near the base of the hole at Site 672 (Mascle, Moore, et al., 1988). Eocene sediments are also observed from the Discoaster bifax Subzone (CP14a) at Site 674. Radiolarian biostratigraphy indicates that discrete intervals of middle to upper Eocene sediment alternate with sediment of Oligocene age in Cores 110674A-29X through -43X (Mascle, Moore, et al., 1988).

\section{FAULTING}

Reverse faulting associated with crustal underthrusting was detected at Sites 671, 674, and 676 through repetition of calcareous nannofossil and planktonic foraminifer zones, and at Sites 673,674 , and 676 through reversals in radiolarian biostratigraphy (Fig. 3) (Mascle, Moore, et al., 1988). The most obvious 
fault is indicated by calcareous nannofossils and planktonic foraminifers at Site 671, where an upper Miocene through lower Pleistocene sequence occurs atop a section of approximately the same age. In the lower sequence an additional reverse fault is detected through the repetition of the Calcidiscus macintyrei Zone.

At Site 674 the Discoaster tamalis (CN12a) and the D. pentaradiatus $(\mathrm{CN} 12 \mathrm{c})$ Subzones occur twice in the section, which is evidence that at least one reverse fault is present. In Cores 110$674 \mathrm{~A}-10 \mathrm{X}$ through $-11 \mathrm{X}$, radiolarian Zone 15 of early Oligocene age is detected above late Oligocene Zone R13 $\backslash 14$. This reversed sequence is emplaced within an interval of upper Pliocene sediment and may indicate as many as three thrust faults. Two additional thrust faults are indicated by repetition of radiolarian zones in the lower Oligocene through middle Eocene section at the bottom of the hole (Fig. 3) (Mascle, Moore, et al., 1988).

Two reverse faults are detected at Site 676 through the repetition of nannofossil zones that interrupt the upper Miocene through lower Pleistocene sequence. The upper fault is indicated by the repetition of the Pseudoemiliania lacunosa Zone and the lower one is detected by the repetition of the Discoaster quinqueramus (CN9) through D. neohamatus (CN8) Zones. A reverse fault is indicated in the lower Miocene sequence between Cores $110-676 \mathrm{~A}-31 \mathrm{X}$ and $-32 \mathrm{X}$ by the repetition of radiolarian Zones 9 and 10 (Mascle, Moore, et al., 1988).

At Site 673, frequent repetition of radiolarian zones indicates that the lower Miocene sequence (Cores 110-673B-8X through $-35 \mathrm{X})$ has been tectonically expanded, probably by reverse faulting (Mascle, Moore, et al., 1988).

\section{CONCLUSIONS}

Five of the six sites drilled on Leg 110 explored the deformed sediments of the Barbados Ridge complex. Sites 671, 675, and 676 were drilled at the toe of the accretionary prism whereas Sites 673 and 674 penetrated intensely disturbed sediments upslope from the deformation front. Site 672 investigated the relatively undisturbed sediments of the abyssal plain to document the sedimentary sequence entering the subduction zone. The main objective of this leg was realized at Site 671 when the décollement between the descending Atlantic Plate and the offscraped accretionary prism was penetrated. Conclusive evidence was obtained at four Leg 110 sites for reverse faulting of sediments within the accretionary prism due to tectonic movements along the décollement zone. At Site 671 the most obvious example of reverse thrust faulting emplaced a lower Pleistocene through upper Miocene section above sediments of early Pleistocene age.

Nannofossiliferous sediments were recovered on Leg 110 that ranged in age from middle Eocene to early Pleistocene. Numerous gaps occur in the sedimentary sequence that may be a result of episodes of increased dissolution or of tectonic disturbance. Miocene sediments were particularly affected by dissolution at all Leg 110 Sites. Early to middle Miocene assemblages were rare to absent and all but the uppermost Miocene sediments were represented by intensely etched, low-diversity assemblages. Episodic rises in the Miocene CCD may be responsible for the patterns of preservation observed in these sediments. Although Pliocene/Pleistocene sediments are generally well preserved at Leg 110 sites, no record of late Pleistocene sedimentation was recovered. Paleogene sediments were often recrystallized and ranged in preservation from good to poor.

\section{ACKNOWLEDGMENTS}

I thank Merton Hill, David Watkins, James Bergen, and Sherwood Wise for their helpful taxonomic discussions and advice during this project. I also thank Clifford Wright for preparing samples and drafting figures for this manuscript.

\section{REFERENCES}

Bergen, J., 1984. Calcareous nannoplankton from Deep Sea Drilling Project Leg 78A: evidence for imbricate underthrusting at the Lesser Antillian active margin. In Biju-Duval, B., Moore, C., et al., Init. Repts. DSDP, 78A: Washington (U.S. Govt. Printing Office), 411434.

Berger, W. H., and Von Rad, U., 1972. Cretaceous and Cenozoic sediments from the Atlantic Ocean. In Hays, D. E., and Pimm, A. C., et al., Init. Repts. DSDP, 14: Washington (U.S. Govt. Printing Office), 787-954.

Berggren, W. A., 1977. Late Neogene planktonic foraminiferal biostratigraphy of the Rio Grande Rise (South Atlantic). Mar. Micropaleontol., 2, 3:265-313.

Berggren, W. A., Kent, D. V., and Van Couvering, J. A., 1985. Neogene geochronology and chronostratigraphy. In Snelling, N. J. (Ed.), Geochronoloqy of the geologic time scale. Geol. Soc. London, Mem. 10:211-260.

Bolli, H. M., and Premoli-Silva, I., 1973. Oligocene to Recent planktonic foraminifera and stratigraphy of the Leg 15 Sites in the Caribbean Sea. In Edgar, N. T., and Saunders, J. B., et al., Init. Repts. DSDP, 15: Washington (U.S. Govt. Printing Office), 475-497.

Bramlette, M. N., and Sullivan, F. R., 1961. Coccolithophorids and related nannoplankton of the early Tertiary of California. Micropaleontoloqy, 7:129-174.

Bukry, D., 1973. Coccolith biostratigraphic zonation. In Edgar, N. T., Saunders, J. B., et al., Init. Repts. DSDP, 15: Washington (U.S. Govt. Printing 0ffice), 685-703.

1975. Coccolith and silicoflagellate stratigraphy, northwestern Pacific Ocean, Deep Sea Drilling Project Leg 32. In Larson, R. L., Moberly, R., et al., Init. Repts. DSDP, 32: Washington (U.S. Govt. Printing Office), 677-702.

Gartner, S., 1977. Calcareous nannofossil biostratigraphy and revised zonation of the Pleistocene. Mar. Micropaleontol., 2:1-25.

Hay, W. W., 1970. Calcareous nannofossils from cores recovered on DSDP Leg 4. In Bader, R. G., Gerard, R. D., et al., Init. Repts. DSDP, 4: Washington (U.S. Govt. Printing Office), 455-503. 1961. Note on the preparation of samples for discoasterids. J. Paleontol., 35:873.

Mascle, A., Moore, J. C., Taylor, E., et al., 1988. Proc. ODP, Init. Repts., 110: College Station, TX (Ocean Drilling Program).

Okada, H., and Bukry, D., 1980. Supplementary modification and introduction of code numbers to the "Low latitude coccolith biostratigraphic zonation" (Bukry, 1973, 1975). Mar. Micropaleontol., 5: 321-325.

Riedel, W. R., and Sanfilippo, A., 1978. Stratigraphy and evolution of tropical Cenozoic radiolarians. Micropaleontoloqy. 24:61-96.

Saunders, J. B., Bernoulli, D., Mueller-Merz, E., Oberhansil, H., PerchNielsen, K., Riedel, W. R., Sanfilippo, A., and Torrini, R., Jr., 1984. Stratigraphy of Late Middle Eocene to Early Oligocene in Bath Cliff section Barbados, West Indies. Micropaleontology, 30: 390-425.

Van Andel, T. H., 1975. Mesozoic/Cenozoic calcite compensation depth and the global distribution of calcareous sediments. Earth Planet. Sci. Lett., 26:187-194.

Wright, A., 1984. Sediment distribution and depositional processes operating in the Lesser Antilles Intraoceanic Island Arc, eastern Caribbean. In Biju-Duval, B., Moore, J. C., et al., Init. Repts. DSDP, 78A: Washington (U.S. Govt. Printing Office), 301-324.

Date of initial receipt: 15 February 1988

Date of acceptance: 21 December 1988

Ms 110B-132 


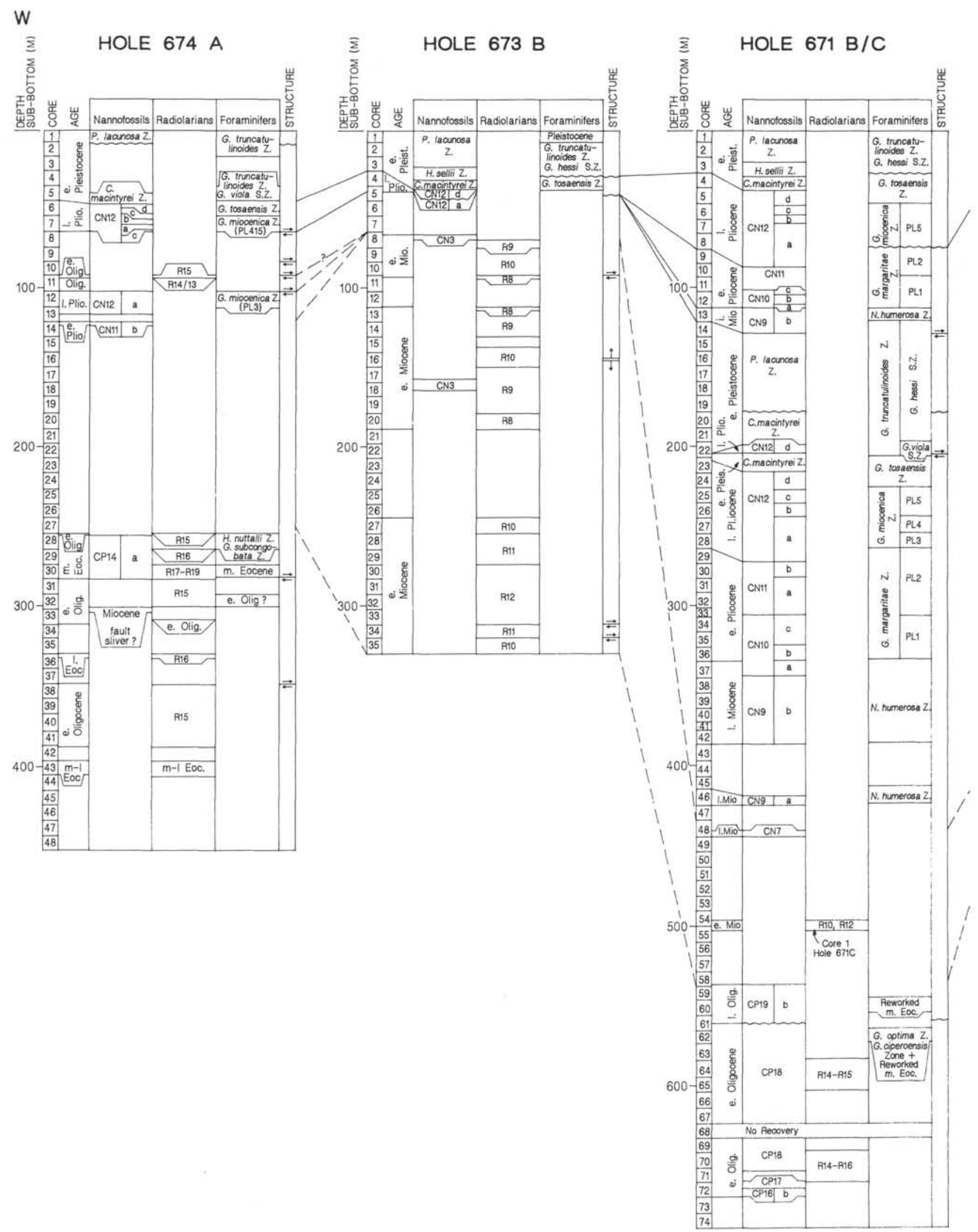

Figure 3. Biostratigraphic summary and correlation of Leg 110 sites. The nannofossil zonation used in this study is modified from Bukry (1973, 1975), Gartner (1977), Okada and Bukry (1980), and Bergen (1984). Radiolarian biostratigraphy is based on the zonation schemes of Riedel and Sanfilippo (1978) and Saunders et al. (1984). Planktonic foraminifer zones employed are those of Berggren (1977) and Bolli and Premoli-Silva (1973). 
BIOSTRATIGRAPHIC SUMMARY
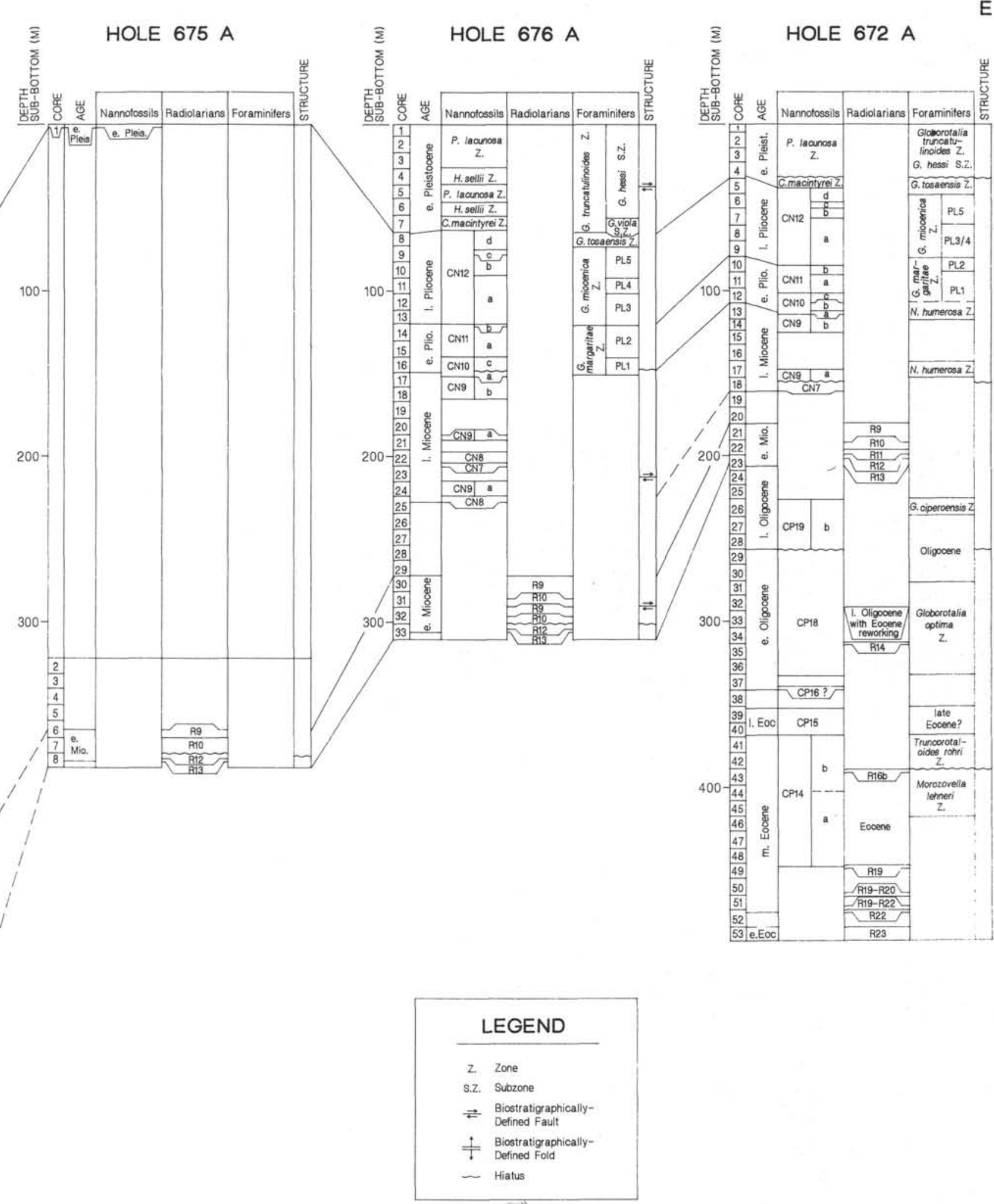

Figure 3 (Continued). 


\section{APPENDIX} below.

Calcareous nannofossil species considered in this study are listed

Sphenolithus abies Deflandre, 1953

Cyclicarqolithus abisectus (Muller) Bukry, 1973

Ceratolithus acutus, Gartner and Bukry, 1974 Helicosphaera ampliaperta Bramlette and Wilcoxon, 1967

Amaurolithus amplificus (Bukry and Percival) Gartner and Bukry, 1975

Ceratolithus armatus Muller, 1974

Discoaster asymmetricus Gartner, 1969

Discoaster barbadiensis Tan Sin Hok, 1927

Discoaster berqqrenii Bukry, 1971

Chiasmolithus bidens (Bramlette and Sullivan) Hay and Mohler, 1967

Braarudosphaera biqelowi (Gran and Braarud) Deflandre, 1947

Zyqrhablithus bijuqatus (Deflandre) Deflandre, 1959

Reticulofenestra bisecta (Hay Mohler and Wade) Roth, 1973

Discoaster bollii Martini and Bramlette, 1963

Discoaster brouweri Tan Sin Hok, 1927

Gephyrocapsa caribbeanica Boudreaux and Hay, 1969

Triquetrorhabdulus carinatus Martini, 1965

Helicosphaera carteri (Wallach) Kamptner, 1954

Discoaster challenqeri Bramlette and Riedel, 1954

Sphenolithus ciperoensis Bramlette and Wilcoxon, 1967

Rhabdosphaera claviqera Murray and Blackmann, 1898

Helicosphaera compacta Bramlette and Wilcoxon, 1967

Ceratolithus cristatus Kamptner, 1950

Discoaster deflandrei Bramlette and Riedel, 1954

Campylosphaera dela (Bramlette and Sullivan) Hay and Mohler, 1967

Amaurolithus delicatus Gartner and Bukry, 1975

Sphenolithus distentus (Martini) Bramlette and Wilcoxon, 1967

Crenalithus doronicoides (Black and Barnes) Roth, 1973

Coccolithus eopelaqicus (Bramlette and Riedel) Bramlette and Sullivan, 1961

Cyclicarqolithus floridanus (Roth and Hay) Bukry, 1971

Micrantholithus flos Deflandre, 1954

Coccolithus formosus (Kamptner) Wise, 1973

Scapholithus fossilis Deflandre, 1954

Gephycapsa sp. small

Chiasmolithus qrandis (Bramlette and Riedel) Radomski, 1968

Discoaster hamatus Martini and Bramlette, 1963

Sphenolithus heteromorphus Deflandre, 1953

Reticulofenestra hillae Bukry and Percival, 1971

Pontosphaera laponica (Takayama) Burns, 1973

Pseudoemiliania lacunosa (Kamptner) Gartner, 1969
Calcidiscus leptoporus (Murray and Blackman) and Loeblich and Tappen, 1978

Calcidiscus macintyrei (Bukry and Bramlette) and Loeblich and Tappen, 1978

Sphenolithus moriformis (Bronnimann and Stradner) Bramlette and Wilcoxon, 1967

Discoaster neohamatus Bukry and Bramlette, 1969

Coronocyclus nitescens (Kamptner) Bramlette and Wilcoxon, 1967

Gephyrocapsa oceanica Kamptner, 1943

Coccolithus pelaqicus (Wallich) Schiller, 1930

Discoaster pentaradiatus Tan Sin Hok, 1927

Hayaster perplexus (Bramlette and Riedel) Bukry, 1973

Pontosphaera spp.

Sphenolithus predistentus Bramlette and Wilcoxon, 1967

Amaurolithus primus (Bukry and Percival) Gartner and Bukry, 1975

Sphenolithus pseudoradians Deflandre, 1952

Reticulofenestra pseudoumbilica (Gartner) Gartner, 1969

Discoaster quinqueramus Gartner, 1969

Cribrocentrum reticulatum (Gartner and Smith) Perch-Nielsen, 1971

Helicosphaera reticulata Bramlette and Wilcoxon, 1967

Ceratolithus ruqosus Bukry and Bramlette, 1968

Triquetrorhabdulus ruqosus Bramlette and Wilcoxon, 1967

Discoaster saipanensis Bramlette and Riedel, 1954

Helicosphaera sellii (Bukry and Bramlette) and Jafar and Martini, 1975

Umbilicosphaera siboqae (Weber-van-Bysse) Gaardner, 1970

Chiasmolithus solitus (Bramlette and Sullivan) Lycker, 1968

Discoaster surculus Martini and Bramlette, 1963

Discoaster tamalis Kamptner, 1967

Thoracosphaera spp. Amaurolithus tricorniculatus (Gartner) Gartner and Bukry, 1975

Discoaster tanii Bramlette and Riedel, 1954

Reticulofenestra umbilica (Levin) Martini and Ritzkowski, 1968

Discoaster variabilis Martini and Bramlette, 1963

Taxonomic Notes

Discoaster sp. cf. D. tamalis

Description. Discoaster sp. cf. D. tamalis is a form that has four rays intersecting at right angles with bifurcations at the tips of each ray. No ornamentation is apparent in the central area. This form is easily confused with $D$. tamalis when dissolution has removed the delicate bifurcations. Under conditions of increased dissapation, $D$. tamalis is distinguished by the thicker appearance of its rays.

Occurrence. Discoaster sp. cf. D. tamalis occurs at Sites 671, 672, and 676 and extends above the range of $D$. tamalis into the $D$. surculus Zone. Under conditions of increased sample dissolution the upper boundary of the $D$. tamalis Zone is obscured by this similar form. 